\title{
Brachybacterium squillarum sp. nov., isolated from salt-fermented seafood
}

\author{
Seong-Kyu Park, Min-Soo Kim, Mi-Ja Jung, Young-Do Nam, Eun-Jin Park, \\ Seong Woon Roh and Jin-Woo Bae
}

\author{
Correspondence \\ Jin-Woo Bae \\ baejw@khu.ac.kr
}

\author{
Department of Life and Nanopharmaceutical Sciences and Department of Biology, Kyung Hee \\ University, Seoul 130-701, Republic of Korea
}

\begin{abstract}
A Gram-positive bacterium, strain $\mathrm{M}-6-3^{\top}$, was isolated from salt-fermented seafood in Korea. The organism grew in $0-10 \%(\mathrm{w} / \mathrm{v}) \mathrm{NaCl}$ and at $25-37{ }^{\circ} \mathrm{C}$, with optimal growth occurring in $5 \%$ $\mathrm{NaCl}$ and at $28-30{ }^{\circ} \mathrm{C}$. The peptidoglycan type was variation $\mathrm{A} 4 \gamma$ with meso-diaminopimelic acid as the diagnostic cell-wall diamino acid. The polar lipid profile of strain $M-6-3^{\top}$ consisted of diphosphatidylglycerol, phosphatidylglycerol, an unidentified phospholipid and an unknown glycolipid. Strain M-6-3 ${ }^{\top}$ contained MK-7 as the major component of the quinone system and anteiso- $\mathrm{C}_{15: 0}(62.1 \%)$ as the predominant fatty acid. Based on 16S rRNA gene sequence similarity studies, strain M-6-3 ${ }^{\top}$ was most closely related to Brachybacterium rhamnosum LMG $19848^{\top}(98.5 \%)$. The $\mathrm{G}+\mathrm{C}$ content of the genomic DNA was $71.5 \mathrm{~mol} \%$ and the mean DNA-DNA hybridization value with reference strains was $14.32 \pm 2.0 \%$. Based on phenotypic, genotypic and phylogenetic analyses, it is proposed that strain $M-6-3^{\top}$ represents a novel species for which the name Brachybacterium squillarum sp. nov. is proposed; the type strain is $M-6-3^{\top}$ $\left(=\right.$ KACC $14221^{\top}=$ JCM $\left.16464^{\top}\right)$.
\end{abstract}

The genus Brachybacterium belongs to the family Dermabacteraceae, class Actinobacteria, and was first proposed by Collins et al. (1988) to accommodate Brachybacterium faecium. Cells of B. faecium, isolated from poultry deep litter, were Gram-positive, coccoid-shaped and grew under aerobic conditions (Collins et al., 1988). Since this genus was established in 1988, twelve species have been described based on phenotypic, biochemical and chemotaxonomic characteristics: Brachybacterium alimentarium, B. conglomeratum, B. faecium, B. fresconis, B. muris, B. nesterenkovii, B. paraconglomeratum, B. phenoliresistens, B. rhamnosum, B. sacelli, $B$. tyrofermentans and $B$. zhongshanense (Buczolits et al., 2003; Chou et al., 2007; Collins et al., 1988; Gvozdyak et al., 1992; Heyrman et al., 2002; Schubert et al., 1996; Takeuchi et al., 1995; Zhang et al., 2007). While carrying out a study examining the microbial diversity in salt-fermented food, a novel species, M-6- $3^{\mathrm{T}}$, was isolated from a salt-fermented food made of tiny shrimp.

A pure culture of strain M-6- $3^{\mathrm{T}}$ was isolated by using several rounds of dilution streaking on marine agar (MA). To identify the 16S rRNA gene sequence, PCR was performed using a PCR Pre-Mix (SolGent) and two previously described, bacteria-specific primers (8F, 1492R) (Baker

The GenBank/EMBL/DDBJ accession number for the 16S rRNA gene sequence of strain M-6-3' is GQ339911.

A supplementary table and a supplementary figure are available with the online version of this paper. et al., 2003). Sequences were obtained with a PRISM 3730XL DNA analyser (Applied Biosystems). Based on sequence similarities, four primers $(8 \mathrm{~F}, 968 \mathrm{~F}, 518 \mathrm{R}$ and $1492 \mathrm{R}$ ) were used to obtain the majority of the M- $6-3^{\mathrm{T}} 16 \mathrm{~S}$ rRNA gene sequence and the fragments were assembled using SeqMan software (DNASTAR). The 16S rRNA sequences of the isolate and its relatives were aligned using CLUSTAL $\mathrm{X}$ (1.83) (Thompson et al., 1997) and a phylogenetic tree was reconstructed using MEGA4 (Tamura et al., 2007). In addition, neighbour-joining was used to reconstruct a phylogenetic tree (Saitou \& Nei, 1987). One thousand randomly chosen bootstrap replications were set up for the phylogenetic tree, as shown in Fig. 1. Analysis of 16S rRNA gene sequences based on the EzTaxon server (Chun et al., 2007) clearly showed that strain M-6- $3^{\mathrm{T}}$ was associated with members of the genus Brachybacterium and closely related to B. rhamnosum LMG $19848^{\mathrm{T}}(98.5 \%)$, B. muris $\mathrm{C} 3 \mathrm{H}-21^{\mathrm{T}}$ (98.3\%), B. nesterenkovii DSM 9573 ${ }^{\mathrm{T}}$ (98.1\%), B. sacelli LMG $20345^{\mathrm{T}}$ (97.9\%), B. fresconis LMG $20336^{\mathrm{T}}$ (97.6\%), B. zhongshanense $\mathrm{JB}^{\mathrm{T}}(97.5 \%)$, B. paraconglomeratum LMG $19861^{\mathrm{T}}(97.5 \%)$, B. faecium DSM $4810^{\mathrm{T}}(97.4 \%), B$. alimentarium CNRZ $925^{\mathrm{T}}(97.4 \%), B$. phenoliresistens phenol-A ${ }^{\mathrm{T}} \quad(97.3 \%), \quad B$. conglomeratum IFO $15472^{\mathrm{T}}$ $(97.2 \%)$ and $B$. tyrofermentans CNRZ $926^{\mathrm{T}}$ (96.9\%). Based on neighbour-joining, maximum-parsimony and maximum-likelihood algorithms including all described members of the genus Brachybacterium and Devriesea agamarum IMP2 ${ }^{\mathrm{T}}$ as an outgroup, strain $\mathrm{M}-6-3^{\mathrm{T}}$ was most closely related to $B$. rhamnosum DSM $10240^{\mathrm{T}}$, B. muris DSM 
$15460^{\mathrm{T}}$ and B. nesterenkovii DSM $9573^{\mathrm{T}}$. Thus, for further analyses, $B$. rhamnosum, $B$. muris and $B$. nesterenkovii were used as reference strains.

To determine the optimal growth conditions for M-6-3 $3^{\mathrm{T}}$, cultures were grown in marine broth $(\mathrm{MB} ; \mathrm{BBL})$ at 4,15 , $25,30,35$ and $45{ }^{\circ} \mathrm{C}$ and $\mathrm{pH} 4.0-13.0$ (at unit intervals). $\mathrm{NaCl}$ tolerance was determined in $\mathrm{MB}$ modified to contain $0,0.5,1,3,5,7,10,15,20,25$ and $30 \%(\mathrm{w} / \mathrm{v}) \mathrm{NaCl}$. Growth was determined by measuring the turbidity of cultures (optical density) at $600 \mathrm{~nm}\left(\mathrm{OD}_{600}\right)$. Growth on MA under anaerobic conditions was checked in an anaerobic chamber filled with a mixture of gases $\left(\mathrm{N}_{2}: \mathrm{H}_{2}: \mathrm{CO}_{2}\right.$ at $\left.90: 5: 5\right)$ for 1 week. Results showed that $\mathrm{M}-6-3^{\mathrm{T}}$ grew at $30{ }^{\circ} \mathrm{C}$ and $\mathrm{pH} 7.0 \pm 0.2$ on MA. Unless otherwise stated, all further tests used to characterize the isolate were performed under these conditions.

Colony and cell morphologies were observed using a light microscope (ECLIPSE 50i, Nikon). Motility tests were performed using BBL motility test medium (BBL). For Gram reactions, a Gram Staining kit (bioMérieux) was used according to the manufacturer's instructions. Oxidase activity was assessed with $1 \%(\mathrm{v} / \mathrm{v}) p$-tetramethyl phenylenediamine (bioMérieux). Catalase activity was determined by observing bubble production after $3 \%$ hydrogen peroxide was added to a sample of M-6- $3^{\mathrm{T}}$ cells. Media containing $0.01 \%(\mathrm{w} / \mathrm{v}) \mathrm{CaCl}_{2}$ and $1 \%(\mathrm{v} / \mathrm{v})$ Tweens 20 , 40, 60 or 80 (Holding \& Collee, 1971) were used to perform Tween decomposition tests. Enzymic activity and acid production from various carbohydrates were determined using API 20E (bioMérieux). Substrate utilization tests were performed using Biolog GP2 Microplates according to the manufacturer's instructions. Differential phenotypic characteristics of strain $\mathrm{M}-6-3^{\mathrm{T}}$ and reference strains are given in Table 1.
Purified cell-wall preparations were obtained by the method of Schleifer \& Kandler (1972) and the amino acids and peptides in peptidoglycan hydrolysates were analysed as described by Groth et al. (1997). The peptidoglycan of strain M-6- $3^{T}$ contained meso-diaminopimelic acid, alanine, glycine, aspartic acid and glutamic acid, as observed in $B$. muris DSM $15460^{\mathrm{T}}$. The peptidoglycan type of strain M-6$3^{\mathrm{T}}$ was A4 $\gamma$ [meso-diaminopimelic acid(D-Glu) $)_{2}$ type] (Schleifer \& Kandler, 1972). These results show that strain M-6-3 $3^{\mathrm{T}}$ was a coherent member of the genus Brachybacterium. To assess cellular fatty acids in strain M6-3 $3^{\mathrm{T}}$, B. rhamnosum DSM $10240^{\mathrm{T}}$, B. muris DSM $15460^{\mathrm{T}}$ and B. nesterenkovii DSM $9573^{\mathrm{T}}$, cells were cultured for $72 \mathrm{~h}$ on $\mathrm{MA}$ at $30{ }^{\circ} \mathrm{C}$ and $\mathrm{pH} 7.0 \pm 0.2$. Cellular fatty acids were extracted as described by the Sherlock Microbial Identification System (MIDI, 1999) and then analysed by GC. The fatty acid profile of strain $\mathrm{M}-6-3^{\mathrm{T}}$ contained a large amount of anteiso- $\mathrm{C}_{15: 0}(62.1 \%)$ and a significant amount of anteiso- $\mathrm{C}_{17: 0}(12.3 \%)$, fatty acids which are common in the profiles of other known species of the genus Brachybacterium (Buczolits et al., 2003; Collins et al., 1988; Gvozdyak et al., 1992; Takeuchi et al., 1995). Additionally, significant amounts of iso- $\mathrm{C}_{16: 0}(13.2 \%)$, iso- $\mathrm{C}_{14: 0}(7.0 \%)$ and iso- $\mathrm{C}_{15: 0}(5.4 \%)$ were also found. The detailed compositions are shown in Table 2. Polar lipids were extracted by using the method of Xin et al. (2000) and detected by using two-dimensional TLC sprayed with detection reagents, according to Tindall (1990). The major lipids found in strain M-6-3 ${ }^{\mathrm{T}}$ included diphosphatidylglycerol, phosphatidylglycerol, an unidentified phospholipid and an unknown glycolipid (see Supplementary Fig. S1 available in IJSEM Online). Menaquinones were extracted, purified and analysed by HPLC as described by Komagata \& Suzuki (1987). As with other species of the genus Brachybacterium, the isolate contained MK-7 as the major

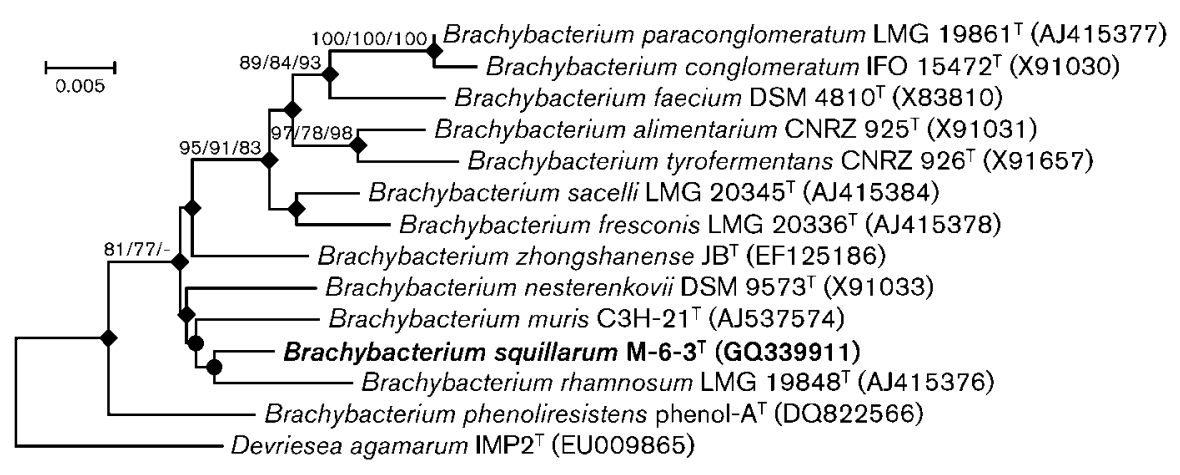

Fig. 1. A phylogenetic consensus tree based on 16S rRNA gene sequences. Filled diamonds indicate corresponding nodes (groupings) that were recovered in phylogenetic consensus trees reconstructed by the neighbour-joining, maximum-parsimony or maximum-likelihood algorithms. Filled circles indicate collective branches that were present in phylogenetic consensus trees reconstructed by both the neighbour-joining and maximum-likelihood algorithms. Numbers at nodes indicate bootstrap values (percentages of 1000 replications) for neighbour-joining, maximum-parsimony and maximum-likelihood trees, respectively. Values lower than $70 \%$ are not indicated. Devriesea agamarum IMP2 ${ }^{\top}$ was included as an outgroup. Bar, 5 substitutions per 1000 nt positions. 
Table 1. Differential characteristics of strain $M-6-3^{\top}$ and members of the genus Brachybacterium

Strains: 1, B. squillarum sp. nov. M-6-3 $3^{\mathrm{T}}$ (data from this study); 2, B. rhamnosum DSM $10240^{\mathrm{T}}$ (data from this study except where marked); 3 , B. muris DSM $15460^{\mathrm{T}}$ (data from this study); 4, B. nesterenkovii DSM $9573^{\mathrm{T}}$ (data from this study except where marked); 5 , B. sacelli LMG $20345^{\mathrm{T}}$ (data from Heyrman et al., 2002); 6, B. fresconis LMG $20336^{\mathrm{T}}$ (data from Heyrman et al., 2002); 7, B. zhongshanense $\mathrm{JB}^{\mathrm{T}}$ (data from Zhang et al., 2007); 8, B. paraconglomeratum LMG $19861^{\mathrm{T}}$ (data from Takeuchi et al., 1995); 9, B. faecium DSM 4810 (data from Collins et al., 1988); 10, B. alimentarium CNRZ $925^{\mathrm{T}}$ (data from Schubert et al., 1996); 11, B. phenoliresistens phenol- $\mathrm{A}^{\mathrm{T}}$ (data from Chou et al., 2007); 12, B. conglomeratum IFO $15472^{\mathrm{T}}$ (data from Takeuchi et al., 1995). +, Positive; -, negative; $(+$ ), weakly positive; ND, not determined.

\begin{tabular}{|c|c|c|c|c|c|c|c|c|c|c|c|c|}
\hline Characteristic & 1 & 2 & 3 & 4 & 5 & 6 & 7 & 8 & 9 & 10 & 11 & 12 \\
\hline Oxidase activity & - & + & + & + & - & - & - & - & - & + & - & - \\
\hline \multicolumn{13}{|l|}{ Growth with: } \\
\hline $5 \% \mathrm{NaCl}$ & + & + & + & - & + & + & + & + & + & + & + & + \\
\hline $10 \% \mathrm{NaCl}$ & + & $(+)$ & + & - & + & + & + & $(+)$ & $(+)$ & + & - & + \\
\hline Urease activity & - & + & + & + & - & + & + & + & - & + & - & $(+)$ \\
\hline Gelatin hydrolysis & + & + & - & - & + & + & + & - & - & + & - & $(+)$ \\
\hline \multicolumn{13}{|l|}{ Acid production from: } \\
\hline D-Glucose & - & + & - & - & + & + & + & + & + & + & + & + \\
\hline D-Mannitol & + & + & - & - & $\mathrm{ND}$ & ND & ND & - & - & $\mathrm{ND}$ & + & - \\
\hline Inositol & + & + & - & - & ND & ND & ND & + & - & ND & + & - \\
\hline D-Sorbitol & - & + & - & - & - & - & + & - & - & - & - & - \\
\hline L-Rhamnose & + & + & - & - & $(+)$ & $(+)$ & + & - & - & + & + & - \\
\hline Sucrose & + & + & - & + & - & - & + & + & - & - & + & + \\
\hline Melibiose & - & + & - & - & - & + & + & - & $\mathrm{ND}$ & + & - & ND \\
\hline Amygdalin & - & + & - & + & $\mathrm{ND}$ & $\mathrm{ND}$ & + & + & $\mathrm{ND}$ & $\mathrm{ND}$ & + & ND \\
\hline L-Arabinose & - & + & - & + & - & - & + & + & $(+)$ & ND & + & + \\
\hline $\begin{array}{l}\text { DNA G }+ \text { C content } \\
(\mathrm{mol} \%)\end{array}$ & 71.5 & $71.5^{*}$ & $\mathrm{ND}$ & $72.0^{*}$ & 70.3 & 70.4 & 71.2 & 68.6 & 69.4 & 73.0 & 70.8 & 70.6 \\
\hline
\end{tabular}

${ }^{\star}$ Data from Buczolits et al. (2003).

component of the quinone system (Buczolits et al., 2003; Chou et al., 2007; Collins et al., 1988; Gvozdyak et al., 1992; Heyrman et al., 2002; Schubert et al., 1996; Takeuchi et al., 1995; Zhang et al., 2007).

Genomic DNA from M-6-3 $3^{\mathrm{T}}$, B. rhamnosum DSM $10240^{\mathrm{T}}$, B. muris DSM $15460^{\mathrm{T}}$ and B. nesterenkovii DSM $9573^{\mathrm{T}}$ was isolated using an UltraClean Microbial DNA Isolation kit (MOBIO Laboratories). The DNA G $+\mathrm{C}$ content of strain $\mathrm{M}-6-3^{\mathrm{T}}$, analysed fluorimetrically using SYBR Green I and

Table 2. Fatty acid compositions of strain $M-6-3^{\top}$ and reference members of the genus Brachybacterium

Strains: 1, B. squillarum sp. nov. M-6-3 $3^{\mathrm{T}} ; 2$, B. rhamnosum DSM $10240^{\mathrm{T}}$; 3, B. muris DSM $15460^{\mathrm{T}}$; 4, B. nesterenkovii DSM $9573^{\mathrm{T}}$. All data shown are from the present study. Values are percentages of total fatty acids. - , Not detected.

\begin{tabular}{|lcccc|}
\hline Fatty acid & $\mathbf{1}$ & $\mathbf{2}$ & $\mathbf{3}$ & $\mathbf{4}$ \\
\hline i- $\mathrm{C}_{14: 0}$ & 7.0 & 5.9 & 4.1 & 5.0 \\
$\mathrm{i}-\mathrm{C}_{15: 1}$ & - & - & 5.7 & - \\
$\mathrm{i}-\mathrm{C}_{15: 0}$ & 5.4 & 7.5 & 4.8 & 5.4 \\
ai- $\mathrm{C}_{15: 0}$ & 62.1 & 65.3 & 73.1 & 89.6 \\
i- $\mathrm{C}_{16: 0}$ & 13.2 & 7.7 & 5.8 & - \\
ai- $\mathrm{C}_{17: 0}$ & 12.3 & 5.6 & 6.5 & - \\
\hline
\end{tabular}

real-time PCR (Gonzalez \& Saiz-Jimenez, 2002), was determined as $71.5 \mathrm{~mol} \%$, using genomic DNA of Escherichia coli K-12 as a calibration reference (Gonzalez \& Saiz-Jimenez, 2002). Cy5-labelled DNA probes and genomespotted microarrays (Bae et al., 2005; Chang et al., 2008) were used to measure DNA-DNA hybridization. Cy5-dUTPlabelled target DNA $(1 \mu \mathrm{g})$ was mixed with hybridization solution containing $50 \%$ formamide, $3 \times$ SSC, $1.25 \mu \mathrm{g}$ unlabelled herring sperm DNA and $0.3 \%$ SDS; $7 \mu \mathrm{l}$ of the mixture was hybridized with probe DNAs on a microarray slide. The microarray slide was placed into a hybridization chamber, boiled for $5 \mathrm{~min}$ to denature the hybridization solution and plunged immediately into a $37{ }^{\circ} \mathrm{C}$ water bath for overnight hybridization. The microarray slide was scanned with a genepix 400A (Axon instruments) microarray scanner and the signal-to-noise ratio of each probe was calculated using a previously reported formula (Loy et al., 2005). DNADNA hybridization data are shown in detail in Supplementary Table S1. The mean DNA-DNA hybridization value with reference strains was $14.32 \pm 2.0 \%$.

Based on phenotypic, genotypic ( $\mathrm{G}+\mathrm{C}$ content and DNADNA hybridization) and chemotaxonomic data, as well as phylogenetic analyses, it is suggested that strain M-6- $3^{\mathrm{T}}$ represents a novel species of the genus Brachybacterium, for which the name Brachybacterium squillarum sp. nov. is proposed. 


\section{Description of Brachybacterium squillarum sp. nov.}

Brachybacterium squillarum (squil.la' rum. L. gen. pl. n. squillarum of/from shrimp).

Cells are $1.0-1.5 \mu \mathrm{m}$ in diameter, coccoid-shaped, nonmotile and Gram-positive. Endospores are not formed. Colonies on MA plates are camel yellow-coloured, circular in form and convex with regular edges. Grows at $25-37^{\circ} \mathrm{C}$; no growth occurs at $45^{\circ} \mathrm{C}$. Grows at $\mathrm{pH} 6.0-9.0$, with optimal growth at $\mathrm{pH} 7.0$, under aerobic conditions. Growth occurs in $0-10 \%(\mathrm{w} / \mathrm{v}) \mathrm{NaCl}$, with optimal growth in $5 \% \mathrm{NaCl}(\mathrm{w} / \mathrm{v})$. Does not grow under anaerobic conditions. Negative for catalase and oxidase activities. Able to hydrolyse Tween 60 , but not Tweens 20,40 or 80 . Analysis using the API 20E system revealed that cells are positive for gelatinase and acid production from Dmannitol, inositol, L-rhamnose and sucrose, but negative for $\beta$-galactosidase (ONPG hydrolysis), L-arginine dihydrolase, lysine decarboxylase, ornithine decarboxylase, citrate utilization, $\mathrm{H}_{2} \mathrm{~S}$ production, urease, tryptophan deaminase, indole production and acetoin production (Voges-Proskauer). They are also negative for acid production from D-glucose, D-sorbitol, melibiose, amygdalin and L-arabinose. In the Biolog GP2 test, dextrin, glycogen, D-arabitol, L-fucose, D-galactose, D-gluconic acid, $\alpha$-D-glucose, maltose, maltotriose, D-mannitol, D-mannose, melezitose, melibiose, D-psicose, raffinose, D-sorbitol, stachyose, sucrose, turanose, pyruvic acid, adenosine, inosine and uridine are oxidized, but not $\alpha$-cyclodextrin, $\beta$-cyclodextrin, inulin, mannan, $N$-acetyl-D-glucosamine, $N$-acetyl- $\beta$-D-mannosamine, amygdalin, L-arabinose, arbutin, cellobiose, D-fructose, D-galacturonic acid, gentiobiose, myo-inositol, lactose, lactulose, methyl $\alpha$-D-galactoside, methyl $\beta$-D-galactoside, 3-methyl glucose, methyl $\alpha$-Dglucoside, methyl $\beta$-D-glucoside, methyl $\alpha$-D-mannoside, palatinose, L-rhamnose, D-ribose, salicin, sedoheptulosan, D-tagatose, trehalose, xylitol, D-xylose, acetic acid, $\alpha$ hydroxybutyric acid, $\beta$-hydroxybutyric acid, $\gamma$-hydroxybutyric acid, $p$-hydroxyphenylacetic acid, $\alpha$-ketoglutaric acid, $\alpha$-ketovaleric acid, lactamide, D-lactic acid methyl ester, L-lactic acid, D-malic acid, L-malic acid, pyruvic acid methyl ester, succinic acid monomethyl ester, propionic acid, succinamic acid, succinic acid, $\mathrm{N}$-acetyl-L-glutamic acid, L-alaninamide, D-alanine, L-alanine, L-alanyl glycine, L-asparagine, L-glutamic acid, glycyl L-glutamic acid, L-pyroglutamic acid, L-serine, putrescine, 2,3-butanediol, glycerol, 2'-deoxy adenosine, thymidine, AMP, TMP, UMP, D-fructose 6-phosphate, $\alpha$-D-glucose 1-phosphate, D-glucose 6 -phosphate or DL- $\alpha$-glycerol phosphate. The diagnostic cellwall diamino acid is meso-diaminopimelic acid and the peptidoglycan type is A4 $\gamma$, containing amino acids mesodiaminopimelic acid, alanine, glycine, aspartic acid and glutamic acid. The polar lipid profile consists of diphosphatidylglycerol, phosphatidylglycerol, and phosphoand glycolipids. The major menaquinone is MK-7. The major fatty acids are anteiso- $\mathrm{C}_{15: 0}$, anteiso- $\mathrm{C}_{17: 0}$, iso- $\mathrm{C}_{14: 0}$, iso- $\mathrm{C}_{15: 0}$ and iso- $\mathrm{C}_{16: 0 \text {. }}$.
The type strain is $\mathrm{M}-6-3^{\mathrm{T}}$ (=KACC $14221^{\mathrm{T}}=\mathrm{JCM}$ $\left.16464^{\mathrm{T}}\right)$, isolated from a salt-fermented seafood. The DNA G $+\mathrm{C}$ content of the type strain is $71.5 \mathrm{~mol} \%$.

\section{Acknowledgements}

We thank Dr J. P. Euzéby (École Nationale Vétérinaire de Toulouse, France) for etymological advice. This work was supported by the TDPAF (Technology Development Program for Agriculture 160 and Forestry).

\section{References}

Bae, J. W., Rhee, S. K., Park, J. R., Chung, W. H., Nam, Y. D., Lee, I., Kim, H. \& Park, Y. H. (2005). Development and evaluation of genomeprobing microarrays for monitoring lactic acid bacteria. Appl Environ Microbiol 71, 8825-8835.

Baker, G. C., Smith, J. J. \& Cowan, D. A. (2003). Review and reanalysis of domain-specific $16 \mathrm{~S}$ primers. J Microbiol Methods 55, 541555.

Buczolits, S., Schumann, P., Weidler, G., Radax, C. \& Busse, H.-J. (2003). Brachybacterium muris sp. nov., isolated from the liver of a laboratory mouse strain. Int J Syst Evol Microbiol 53, 1955-1960.

Chang, H. W., Nam, Y. D., Jung, M. Y., Kim, K. H., Roh, S. W., Kim, M. S., Jeon, C. O., Yoon, J. H. \& Bae, J. W. (2008). Statistical superiority of genome-probing microarrays as genomic DNA-DNA hybridization in revealing the bacterial phylogenetic relationship compared to conventional methods. J Microbiol Methods 75, 523-530.

Chou, J. H., Lin, K. Y., Lin, M. C., Sheu, S. Y., Wei, Y. H., Arun, A. B., Young, C. C. \& Chen, W. M. (2007). Brachybacterium phenoliresistens sp. nov., isolated from oil-contaminated coastal sand. Int J Syst Evol Microbiol 57, 2674-2679.

Chun, J., Lee, J. H., Jung, Y., Kim, M., Kim, S., Kim, B. K. \& Lim, Y. W. (2007). EzTaxon: a web-based tool for the identification of prokaryotes based on 16S ribosomal RNA gene sequences. Int J Syst Evol Microbiol 57, 2259-2261.

Collins, M. D., Brown, J. \& Jones, D. (1988). Brachybacterium faecium gen. nov., sp. nov., a coryneform bacterium from poultry deep litter. Int J Syst Bacteriol 38, 45-48.

Gonzalez, J. M. \& Saiz-Jimenez, C. (2002). A fluorimetric method for the estimation of $\mathrm{G}+\mathrm{C}$ mol\% content in microorganisms by thermal denaturation temperature. Environ Microbiol 4, 770-773.

Groth, I., Schumann, P., Rainey, F. A., Martin, K., Schuetze, B. \& Augsten, K. (1997). Bogoriella caseilytica gen. nov., sp. nov., a new alkaliphilic actinomycete from a soda lake in Africa. Int J Syst Bacteriol 47, 788-794.

Gvozdyak, O. R., Nogina, T. M. \& Schumann, P. (1992). Taxonomic study of the genus Brachybacterium: Brachybacterium nesterenkovii sp. nov. Int J Syst Bacteriol 42, 74-78.

Heyrman, J., Balcaen, A., De Vos, P., Schumann, P. \& Swings, J. (2002). Brachybacterium fresconis sp. nov. and Brachybacterium sacelli sp. nov., isolated from deteriorated parts of a medieval wall painting of the chapel of Castle Herberstein (Austria). Int J Syst Evol Microbiol 52, 1641-1646.

Holding, A. J. \& Collee, J. G. (1971). Routine biochemical tests. Methods Microbiol 6A, 1-32.

Komagata, K. \& Suzuki, K. (1987). Lipid and cell-wall analysis in bacterial systematics. Methods Microbiol 19, 161-207.

Loy, A., Schulz, C., Lücker, S., Schöpfer-Wendels, A., Stoecker, K., Baranyi, C., Lehner, A. \& Wagner, M. (2005). 16S rRNA gene-based oligonucleotide microarray for environmental monitoring of the 
betaproteobacterial order "Rhodocyclales". Appl Environ Microbiol 71, 1373-1386.

MIDI (1999). Sherlock Microbial Identification System Operating Manual, version 3.0. Newark, DE: MIDI, Inc.

Saitou, N. \& Nei, M. (1987). The neighbor-joining method: a new method for reconstructing phylogenetic trees. Mol Biol Evol 4, 406425.

Schleifer, K. H. \& Kandler, O. (1972). Peptidoglycan types of bacterial cell walls and their taxonomic implications. Bacteriol Rev 36, 407477.

Schubert, K., Ludwig, W., Springer, N., Kroppenstedt, R. M., Accolas, J. P. \& Fiedler, F. (1996). Two coryneform bacteria isolated from the surface of French Gruyère and Beaufort cheeses are new species of the genus Brachybacterium: Brachybacterium alimentarium sp. nov. and Brachybacterium tyrofermentans sp. nov. Int J Syst Bacteriol 46, 81-87.

Takeuchi, M., Fang, C.-X. \& Yokota, A. (1995). Taxonomic study of the genus Brachybacterium: proposal of Brachybacterium conglomeratum sp. nov., nom. rev., Brachybacterium paraconglomeratum sp. nov., and Brachybacterium rhamnosum sp. nov. Int J Syst Bacteriol 45, 160-168.

Tamura, K., Dudley, J., Nei, M. \& Kumar, S. (2007). MEGA4: molecular evolutionary genetics analysis (MEGA) software version 4.0. Mol Biol Evol 24, 1596-1599.

Thompson, J. D., Gibson, T. J., Plewniak, F., Jeanmougin, F. \& Higgins, D. G. (1997). The CLUSTAL_X windows interface: flexible strategies for multiple sequence alignment aided by quality analysis tools. Nucleic Acids Res 25, 4876-4882.

Tindall, B. J. (1990). Lipid composition of Halobacterium lacusprofundi. FEMS Microbiol Lett 66, 199-202.

Xin, H., Itoh, T., Zhou, P., Suzuki, K., Kamekura, M. \& Nakase, T. (2000). Natrinema versiforme sp. nov., an extremely halophilic archaeon from Aibi salt lake, Xinjiang, China. Int J Syst Evol Microbiol 50, 1297-1303.

Zhang, G., Zeng, G., Cai, X., Deng, S., Luo, H. \& Sun, G. (2007). Brachybacterium zhongshanense sp. nov., a cellulose-decomposing bacterium from sediment along the Qijiang River, Zhongshan City, China. Int J Syst Evol Microbiol 57, 2519-2524. 